\title{
BANCO NACIONAL DE CUBA v. SABBATINO: NEW WINE IN OLD BOTTLES
}

\author{
Frank G. Dawson† \\ BURNS H. WESTON†
}

$\mathrm{O}$ N February 18, 1963, the United States Supreme Court issued a Writ of Certiorari in Banco Nacional de Cuba v. Sabbatino. ${ }^{1}$ It is one of the most important and controversial cases involving the nationalization of alien property to arise in recent years. As such, it has been the subject of extensive scholarly comment. Most commentators, however, have focused upon the conflicts of laws questions presented by the interposition of the Act of State Doctrine. ${ }^{2}$ Only a few have broached,

+ Members of the New York State Bar.

1372 U.S. 905 (1963), reviewing 307 F.2d 845 (2d Cir. 1962), affirming 193 F. Supp. 375 (S.D.N.Y. 1961) [hereinafter cited as "Banco Nacional"].

2 See, e.g., Coerper, The Act of State Doctrine in the Light of the Sabbatino Case, 56 AMr. J. INT'L L. 143 (1962); Domke and Baade, Nationalization of Foreign-Owned Property and the Act of State Doctrine-Two Speeches, 1963 DuKE L.J. 269; Falk, Toward a Theory of the Participation of Domestic Courts in the International Legal Order: A Critique of Banco Nacional de Cuba v. Sabbatino, 16 RUTGERS L. Rev. 1 (1961); Lillich, $A$ Pyrrhic Victory at Foley Square: The Second Circuit and Sabbatino, 8 VILL. L. REv. 155 (1963); Reeves, The Cuban Situation: The Political and Economic Relations of the United States and Cuba, 17 Bus. LAw. 980 (1962); Stevenson, The Sabbatino Case-Three Steps Forward and Two Steps Back, 57 AM. J. INT'L L. 97 (1963). The case is also commented upon and noted in 4 ARIz. L. REv. 78 (1962); 3 B.C. IND. \& Comm. L. Rev. 282 (1962); 49 Calif. L. Rev. 979 (1961); 62 Colum. L. Rev. 1278 (1962); 47 Cornell L.Q. 659 (1962); II De Paul L. Rev. 765 (1962); 30 FordhaM L. Rev. 523 (1962); 75 Harv. L. Rev. 1607 (1962); 47 Iowa L. Rev. 765 (1962); 60 Mich. L. Rev. 231 (1961); 8 N.Y.L.F. 148 (1962); 37 N.Y.U.L. REv. 155 (1962); 34 RockY M.T. L. REv. 563 (1961); 36 ST. JOHN's L. Rev. 159 (1961); I4 Stan. L. Rev. 172 (1961); 13 Syracuse L. Rev. 165 (1961); 1962 Wrs. L. Rev. 386; 111 U. PA. L. Rev. 842 (1963); 110 U. PA. L. REv. 122 (1961); 23 U. PITT. L. REV. 816 (1962).

It is arguable however, that Banco Nacional is not an Act of State case at all. Plaintiff was not a former property owner secking to invalidate the title of a third party who had allegedly acquired title from the depriving State. Instead, plaintiff was the agent of the depriving State itself and was seeking enforcement of its nationalization measure in our courts. In traditional Act of State cases, however, a domestic court's reluctance to review the validity of a third party's title reflects an unwillingness to shift the loss to a third party purchaser for value. This has led courts to make enforcement of the doctrine depend upon such ephemeral concepts as retroactive recognition in order to validate title, or upon public policy or deference to the Executive to strike it down. The foreign government whose act is questioned is not a litigant in such cases and is not directly affected by the decision. See generally, Reeves, Act of State Doctrine and Rule of Law-A Reply, 54 AM. J. INT'L L. 141 (1960); Zander, The Act of State Doctrine, 53 AM. J. INT'L L. 826 (1959); 75 HARv. L. Rev. 1607 (1962). 
and then only briefly, the remaining issues raised ${ }^{3}$ - those bearing upon that area of customary international law commonly called the International Responsibility of States for Injuries to the Person and Property of Aliens. ${ }^{4}$ This essay seeks to explore these remaining provocative issues from a policy oriented perspective.

It is here postulated that the district court and the court of appeals, without adequate appraisal invoked and applied normatively ambiguous and ostensibly self-actuating "rules" largely inspired by pre-World War I events-rules which reflect more the cultural preferences of the investing community than the realities of the contemporary world. We believe that the viability of the Law of State Responsibility would be vastly enhanced were putative principles divorced from contexts in which they have dubious significance and vindicated as meaningful guidelines for judicial inquiry where they have genuine relevance.

The performance of this task-that is, the rational search for and application of policy to a world of acts and events which confront the decision-maker and actually condition his decision-cannot be achieved by the mere repetition of inherited abstractions. At the very least, a decision-maker must realistically examine the nature of the claimants and their objectives, appraise the full factual context within which the claims have arisen, clarify the community policies at stake in the case presented and make a discriminating analysis of the potential grounds for decision based upon the foregoing inquiry. It is hoped that such a policy oriented analysis of all the factors which surely influenced the district court and the court of appeals in Banco Nacional will help to minimize the widespread misconception that economic, political and social considerations are not "legal" considerations and, therefore, irrelevant in resolving disputes under international law. ${ }^{5}$

\section{The Claimants and Their Objectives}

On October 10, 1960, Banco Nacional de Cuba, financial agent of the Republic of Cuba, ${ }^{6}$ brought suit to recover proceeds derived from the sale of a sugar consignment by plaintiff's assignor, a wholly-owned Cuban

3 See Falk, supra note 2; Reeves, supra note 2; Stevenson, supra note 2; 49 CALIF. L. REv. 979 (1961).

4 Hereinafter called "the Law of State Responsibility."

5 For excellent expositions of this misconception, see Kaplan \& Katzenbach, ThE Political Foundations of Internatronal Law ch. 1 (1961); McDougal, Perspectives for an International Law of Human Dignity, STUDIEs IN WORLD PUBLIC ORDER 987-1019 (1960).

6 The bank was organized under the laws of the Republic of Cuba in 1948. At the commencement of this action, fifty per cent of its capital stock plus one share was owned by the Cuban Government. It was subsequently reorganized and is now whollyowned by the Republic of Cuba. Brief for Appellant, p. 2, Banco Nacional, 307 F.2d 845 (2d Cir. 1962). 
Government corporation. The complaint alleged conversion by Farr, Whitlock \& Co., an American commodity broker which had negotiated the sale, and Peter Sabbatino, court-appointed receiver for Compañía Azucarera Vertientes-Camaguey, ${ }^{7}$ a nationalized American-owned Cuban corporation and original owner of the sugar in question. ${ }^{8}$ Defendants Farr-Whitlock and Sabbatino answered that plaintiff Banco Nacional had no title to the sugar because it was located outside Cuba's territorial jurisdiction when C.A.V. was nationalized. While the district court and the court of appeals rejected this claim, they nevertheless held that Banco Nacional had no title because the seizure of C.A.V. by the Cuban Government was in violation of customary international law since the taking had not been reasonably related to a public purpose, the nationalization measure had been discriminatory in nature and the decree had failed to provide "adequate" compensation. Plaintiff-appellant sought unsuccessfully to counter these allegations by claiming that the Act of State Doctrine prohibits United States courts from adjudicating the legality of the Cuban nationalization measures.

Although the formal litigants were Banco Nacional, Farr-Whitlock and Peter Sabbatino (on behalf of C.A.V.), to the extent that the Cuban and United States Governments assume persuasive roles in determining the outcome of decision, they must be recognized as claimants in this case. Thus, while Banco Nacional merely demands payment for the sugar and damages for its conversion, in reality, Cuba, its principal, seeks much more: endorsement in the courts of its greatest critic of a controversial program of socio-economic and political reform which defies more than a half-century of virtually uncontested United States economic and political influence. And while formal United States participation has been limited to statements of judicial deference, ${ }^{8}$ the United States, as a claimant of authority on behalf of all culturally identified and interested persons and institutions, ${ }^{10}$ is deeply interested

7 Hereinafter called "C.A.V."

8 Peter Sabbatino was appointed receiver at the request of a shareholder of the nationalized American-owned Cuban sugar company in Schwartz v. Compañia Azucarera Vertientes Camaguey de Cuba, 28 Misc. 2d 355, 208 N.Y.S.2d 833, aff'd, 12 App. Div. 2d 506, 207 N.Y.S.2d 288 (1960), pursuant to N.Y. Crv. PRAC. ACT, § 977(b), which provides for the appointment of a receiver to manage the remaining assets of a dissolved or nationalized foreign corporation for the benefit of stockholders or creditors in the State of New York.

9 On October 18, 1961, the Legal Adviser to the State Department stated in a letter addressed to counsel for the amici that "whether or not the nationalizations will in the future be given effect in the United States is, of course, for the courts to determine." In a subsequent letter, the Uinder Secretary of State for Economic Affairs wrote: "Our conclusion, in which the Secretary concurs, is that the Department should not comment on matters pending before the courts." Quoted in 307 F.2d at 858 .

10 This is immediately exemplified by the various amici who seek to influence the 
in the ultimate outcome of Banco Nacional. Avowedly at loggerheads with Cuba since May 17, 1959, when, with passage of the Agrarian Reform Law, Cuba began seizing American-owned properties, on July 6, 1960, the United States sharply reduced the Cuban sugar import quota. 11 This action precipitated on the same day the passage in Havana of Law No. 851, pursuant to which the Cuban Government on August 6, 1960, promulgated Executive Power Resolution No. 1, nationalizing C.A.V. Thus, its vicarious interest in the economic well being of American nationals owning ninety per cent of the outstanding stock of C.A.V. aside, the United States Government is vitally concerned with the outcome of this case since the acts and events which served as its genesis seriously challenged goals of United States foreign policy. ${ }^{12}$

Given the identities and the objectives of the formal and informal claimants, it is clear that the case involves far more than the ownership of $\$ 175,250.69$ in sugar proceeds. ${ }^{13}$ The district court and the court of appeals, in effect, were also called upon to resolve, against a background of fear and animosity, an aspect of that politico-economic conflict between collectivism and individualism which today divides the world community into opposing ideological camps. ${ }^{14}$ Whether these courts were properly qualified to meet the challenge thus posed is a question which we do not here seek to resolve. ${ }^{15}$ The underlying conflict must be recalled, however, when exploring not only the unique facts of the case but also the myriad variables of the world social and power processes which inevitably affect both the formal and informal claimants and the decision makers whose authority they invoked.

outcome of this decision. These include the Cuban-American Sugar Company, the Cuban American Sugar Mills Company, the Pan-American Life Insurance Company, the Association of the Bar of the City of New York and the United States Department of Justice. A more detailed statement of interested parties than can here be undertaken, however, would include the many public agencies, private associations and individual persons who, directly or indirectly, will be affected by the outcome of this decision.

11 Exec. Order No. 3355, 25 Fed. Reg. 6414 (1960), acting pursuant to authority granted by Public Law 86-592, 74 Stat. 330, amending the Sugar Act of 1948.

12 The United States Government, intent upon its well publicized policy of economic isolation of the Castro regime, is undoubtedly not only opposed to making the sugar proceeds available to Cuba, but also unwilling to accept any endorsement of the Cuban seizures, which it has several times criticized despite (or, perhaps, as exemplified by) its deference to our judiciary. See, e.g., 43 Dep'T State Bull., No. 1100, pp. 141-42. In 43 Dep't State Bull., No. 1101, p. 171, the United States characterized Cuban Law No. 851 as arbitrary, confiscatory and discriminatory.

13 This comprises the total amount of sugar proceeds derived from the sale, as noted by Judge Dimock in $193 \mathrm{~F}$. Supp. at 376 . Farr-Whitlock's commission of approximately $\$ 1,300$ would be deducted prior to final payment.

14 While we have here posed the two extremes of the world power and social processes, we recognize that there is a scale of infinite gradations between them and the positions of the power blocs which they represent.

15 A perceptive analysis of this question may be found in Falk, supra note 2. 


\section{The Context of Conditions}

It is, of course, the claims and counterclaims as to the requirements of authority which constitute in every case the specific controversy to which decision makers must respond. The opposing claims asserted in Banco Nacional regarding the legality of the seizure of C.A.V. are, therefore, of immediate concern to legal inquiry. Since the objectives sought in this case, however, necessarily embrace all the characteristic demands of formal and informal claimants seeking the protection and enhancement of immediate and long term values in extensive foreign wealth deprivations, ${ }^{16}$ it is necessary to project the full factual context of Banco Nacional if meaningful, authoritative international policy prescriptions are to be discerned. In short, because international law contemplates the reduction of tensions across State boundaries, it must reflect and be responsive to the vicissitudes of all of the socio-economic and political relationships which exist between States.

The global context within which Banco Nacional arose is characterized by an ever growing intensity of unsatisfied demand for wider economic participation and reward. Although Cold War tensions fill the daily headlines, this "revolution of rising expectations" may have greater historical significance. Embracing the entire spectrum of human demand, its impact has been and will continue to be pervasive.

While this revolution is today waged in all quarters, ${ }^{17}$ it is most popularly associated with what Vera Micheles Dean has called "the land of Bandungia"-Asia, Africa, the Middle East and Latin America. ${ }^{18}$ With Mexican and Soviet reforms seen as inspirational precedents, the clock of human endeavor is being pushed forward by centuries. Plagued by poverty, antiquated institutions, political instability and a host of

16 By "foreign wealth deprivations" we mean State action against private alien wealth over which States claim jurisdictional competence, totally or partially depriving alien owners of title or control. This term is used to avoid the normative ambiguities of the words "confiscation" and "expropriation," the former referring to deprivations without the offer of compensation and the latter to deprivations accompanied by such an offer. By "extensive" we refer to alien property seizures commonly referred to as "nationalizations" or "socializations." The expression is employed because it is sometimes possible to characterize even nationalizations as limited deprivations-that is, isolated takings of alien property amounting to an insignificant proportion of the aggregate of foreign-owned wealth in the depriving State, typical of pre-1914 property seizures. The diacritical line, of course, may be difficult to draw. For a more extensive discussion, see Dawson and Weston, Prompt, Adequate and Effective: A Universal Standard of Compensation?, 30 FordHAM L. REV. 727 (1962).

17 Thus, the so-called "Black Revolution," now altering traditional economic and social patterns within the United States, whereby Negro citizens now agitate with increasing vigor for basic human rights, demonstrates that the "revolution of rising expectations" is not confined to nations euphemistically called "less developed" or "underdeveloped."

18 Dean, The Nature of the Non-Western World 13-16 (1957). 
other grievances, the governments of Bandungia today strive not only to eradicate humiliating remnants of past political and economic subservience, but also to adjust to an age of high mass consumption by overcoming complex frustrations generated by the disintegration of ancient ways. ${ }^{19}$ Often challenged by what might be called domestic polycentrism, ${ }^{20}$ these nations must now find new forces of integration. Absent progressive technologies, rapid rates of capital accumulation and strong entrepreneurial classes required for an economic "spurt," 21 however, widespread socio-economic reforms can be neither undertaken nor achieved without the integrative influence of broad public participation in the economic process. For, in addition to the fact that extensive State control enables governments to enforce high levels of saving and investment, the countries of Bandungia have no other institutions capable of mobilizing internal and external capital and other resources. ${ }^{22}$ Assumption of this control often entails the seizure of foreign enterprises for motives which

19 Id. at 212-53. See also HeIrbroner, The Great Ascent (1963); Heitbroner, The Making of Economic Society 198-221 (1962); MYrdal, Rich LANDS AND PoOR (1957); STALEY, THE FUTURE OF UNDERDEVELOPED COUNTRIES (1954).

20 The word "polycentrism" was coined several years ago by Italian Communist Party leader Palmiro Togliatti to describe the comparatively recent diminution of Soviet ideological influence and the proliferation of other centers of effective authority and control within the Communist world. Although not yet noted by the lexicographers, it has become an equally important reality in the West. We use the term here to describe the many foci of political authority frequently found in the less developed nations, resulting from such factors as geographic barriers and inadequate communications, whose principal effect is to foster localism in outlook and personalism in politics. For an excellent series of essays concerning polycentrism within the Communist world, see 42 Survey, A Journal of Soviet \& East European Studies (1962). For the effect of "polycentrism" in Latin America, see LIEuwEN, ARMS AND Politics in Latin America (1960); Tannenbaum, Ten Keys to Latin America ch. 4 (1962).

$21 \mathrm{By}$ "economic spurt" we mean an acceleration in the rate of the industrial output of less developed nations. We use the term in lieu of Professor Walter Rostow's "take-off" which has engendered considerable theoretical debate, principally because it focuses upon the historic economic development of today's industrially advanced nations, not the economically backward. See Rostow, The StaGes of Economic Growth ch. 4 (1960).

22 This is especially true in Latin America where the State has been the traditional initiator and supervisor of economic development, if only for the benefit of a select few. In pre-Colombian times, economic activity was stringently controlled by theocratic aboriginal States which did not recognize the concept of private property as traditionally conceived in the West. After the Conquest, Spanish mercantilist philosophy regulated colonial trade and manufacture through comprehensive, restrictive legislation. Upon independence, dictators and political oligarchies became the arbiters of political endeavor in order to concentrate all wealth and power in their own hands. This authoritarian centralized tradition largely inhibited development of a responsible and significant group of middle-class entrepreneurs capable of acting as an independent force in the national economy. See HerRING, A History of LATIN AMERICA (1956); RIPPy, LATin America (1958); Von Hagen, The AzTec: MAN and Tribe chs. 9, 34 (1958); VON HAGEN, REALM OF THE INCAS chs. 8, 1 (1957). 
may be political and nationalistic ${ }^{23}$ as well as economic. ${ }^{24}$ Hence the "planned, large-scale taking of alien property has become today the most publicized form of foreign wealth deprivation. Though once only matters of limited concern, foreign wealth deprivations are today subjects of national policy." 25

The events which gave genesis to Banco Nacional set no new precedent. ${ }^{26}$ The clash of interests is given unusual intensity, however, by the unique historic relationship between the United States and Latin America in general, and the United States and Cuba in particular.

Although the United States was in 1821 the first non-Latin American government to accord diplomatic recognition to the newly independent Spanish colonies, United States policy in the next forty years, alternating between political neglect and territorial aggrandizement, created among Latin Americans a great reservoir of fear and distrust. ${ }^{27}$ American businessmen and politicians evinced new interest, however, both in Latin American political stability (primarily in Mexico, Central America and the Caribbean) and in inter-American trade and investment in the latter

23 Desires to eliminate foreign economic influence are not, as one commentator correctly observes, confined to newly independent States. They also prevail in nations which, like Iran or Cuba, have been at least nominally independent for years but have only recently felt sufficiently powerful to challenge foreign interests. See White, NAtionalization of Foreign Property 24 (1961).

24 The oft-repeated argument that the seizure of alien property by less developed nations produces only harmful economic effects is challenged in an excellent theoretical treatment by Bronfenbrenner, The Appeal of Confiscation in Economic Development, The Economics of UNDERDEVelopMent 472-94 (ed. Agarwala and Singh 1958).

25 Dawson and Weston, supra note 16 , at 731.

26 The Mexican Revolution of 1910 , with its widespread nationalizations of alienowned lands, mineral deposits and oil refineries demonstrates the early arrival of the "revolution of rising expectations" in Latin America. As Professor Kunz noted: "La Revolucion Mexicana is the all embracing name for a vast social transformation, an attempt to give to the masses, land, hygiene, education, to reshape the country completely, to create a new Mexican nation, to emancipate the Indian, who represents ... more than $90 \%$ of the population, and to liberate the peon through an economic and spiritual higher standard of living." Kunz, The Mexican Expropriations, 17 N.Y.U.L. REv. 327, 328 (1940). Professor Tannenbaum has pointed out the substantial inspirational influence of the Mexican Revolution upon Fidel Castro. TANnenbaum, op. cit. supra note 20 , at 218-27.

27 Despite early Latin American overtures and the Monroe Doctrine notwithstanding, the United States consistently refused to enter into political alliances with her neighbors to the south. Indeed, this period was marked by the disastrous United StatesMexican War, the depredations of American "filibusters" in the Caribbean and Central America, and maneuvers by the United States and Great Britain to assure joint exclusive control over any future Isthmian canal. See HERRING, op. cit. supra note 22, at 320-25, 445-46, 484-86; Perkins, The United States and Latin AMerica, 45-54 (1961). See also generally StuART, LATin AMmerica AND the United States (5th ed. 1955). 
part of the nineteenth century. ${ }^{28}$ While some Latin Americans (largely the ruling oligarchies) welcomed this development with favorable political and economic concessions, others considered the United States a brutish Caliban preying upon Latin America's more innocent and spiritual Ariel. ${ }^{29}$ After 1900 the Roosevelt Corollary provided the theoretical justification for protecting strategic United States interests through military intervention, especially in Central America and the Caribbean..$^{30}$ Accordingly, by the end of World War I, the United States was the major foreign trader and investor in Latin America. ${ }^{31}$ Eventually recognizing that this economic and political penetration had alienated many Latin Americans, the United States, at the Seventh Pan American Conference in Montevideo in 1933, adopted the principle of nonintervention as the corner stone of a Good Neighbor Policy designed to restore confidence in United States leadership at a time when war threatened Europe. ${ }^{32}$ Since 1945, however, notwithstanding the good will of the Thirties, United States-Latin American relations have been marked by profound change. A new nationalism now sweeps Latin America. It "insists upon the recognition of the importance of Latin America in world affairs and is sometimes expressed in hostility to the foreign entrepreneur and vigorous dislike of interference from outside." 33 Today there are widespread and vociferous demands for better health, housing and education and for an end to stratified societies, monocultural export economies and authoritarian rule. ${ }^{34}$ Not surprisingly, the United States,

28 Among the factors which inspired this new interest were the French invasion of Mexico in the $1860 \mathrm{~s}$, revived American faith in republicanism, the opening of the Panama Canal and the development of a strong industrial complex in the United States which sought markets in Latin America for its new products. See Herring, op. cit. supra note 22, at 318-20, 484-86; PerkiNs, op. cit. supra note 27, at 64-86. See also generally STUART, op. cit. supra note 27.

29 In 1900, Uruguayan Jose Enrique Rodo thus characterized the United States in a lengthy and widely read essay. The essay was influential throughout Latin America and may be considered the basic gospel of "Yankeephobia." It was certainly the literary predecessor of recent ex-President of Guatemala Juan José Arévalo's The SHARK AND THE SARDINES (1961).

30 See for a brief but thorough presentation of American foreign policy in Latin America at this time, The United States and Latin America 147-52 (ed. The American Assembly 1959).

31 See for statistics, Senate Subcommittee on American Republics Affairs, United States-Latin American Relations, Compilation of Studies, Study No. 4, S. Doc. No. 125, 86th Cong., 2d Sess. 297-98 (1960).

32 See HerRING, op. cit. supra note 22, at 761-62.

33 PERKINS, op. cit. supra note 27, at 74.

34 See generally, Alexander, Today's Latin America (1962); Benton, The Voice of Latin America (1961); Hirschman, Journeys Toward Progress (1963); Johnson, Politrcal Change in Latin America: The Emergence of the Midde Sectors (1958); Latin Amierica Issues, Essays and Comments (ed. Hirschman, 1961); Social Change in LAtin AmErica Today (ed. Council on Foreign Relations 1960); Szulc, Twilight of 
so long identified with the anciens régimes and so long the predominant foreign participant in Latin American economic life, is often the prime target of reformist zeal..$^{35}$ Since economic dependence is often inversely proportionate to political independence, Latin American hostility is at least understandable.

The ideals and aspirations of the Cuban Revolution epitomize the social, political and economic upheaval now sweeping Latin America. Cuba has always occupied a unique place in United States hemispheric policy. ${ }^{36}$ Although freed from Spain in 1898, her newly acquired independence was only nominal. The bitterly resented Platt Amendment, for example, asserted a United States prerogative to "preserve" Cuban independence through intervention. Incorporated in the 1901 Cuban Constitution, the amendment thus assured United States influence in Cuban internal affairs. ${ }^{37}$ Similarly, a post-1900 influx of United States capital resulted in virtual American domination of the Cuban economy. By 1939, the highpoint of United States economic influence in Cuba, American interests alone controlled about fifty-five per cent of total Cuban sugar production. ${ }^{38}$ The sugar industry, in turn, so dominated Cuban economic life that basic foodstuffs had to be imported with funds derived from sugar sales to the United States. The entire island thus became "enmeshed in a monetary economy dependent primarily upon the export of sugar at a world market price over which Cuba [had] no control."39 Despite repeal of the odious Platt Amendment in 1933 and the gradual decrease of foreign sugar holdings after 1939,40 "Yankee-

The Tyrants (1959); Tannenbaum, op. cit. supra note 20; The United States and Latrn Americi (ed. The American Assembly 1959).

35 The Latin American nations "want to carve a niche for themselves, a special place where they will not only feel secure, but shine forth to the world as a unique historic personality. That is why they are so bitter. That is why the memory of the Platt Amendment rankles so and is seemingly unforgettable. . . The little nations in Latin America want only to be themselves, not tied to American apron strings or led by the American hand. This is a matter about which we will hear much in the next generation or two." TANNENBAum, op. cit. supra note 20, at 214-15.

36 Since the time of Thomas Jefferson, various groups in the United States have contemplated either the outright seizure or purchase of Cuba. See Herring, op. cit. supra note 22, at 398-403; RIPPY, op. cit. supra note 22, at 348-50.

37 "The argument over the Platt Amendment accounted to a large extent for the exceptionally violent character of [recent] political strife in Cuba." INT'L Comi'N OF JURISTs, CUBA AND THE RULE of LAw 26-27 (1962) [hereinafter cited as RuLE of LAw].

38 Id. at 13.

39 Tannenbaum, op. cit. supta note 20 , at 223.

40 By 1958, Cuban capital controlled 121 small mills representing $62.13 \%$ of total Cuban sugar production. Canadian, British and Dutch owned mills had by this time passed into Cuban hands. Of the 161 mills then operating, one, accounting for $0.27 \%$ of total production, was French, three, accounting for $0.95 \%$ of total production, were Spanish, and 36 , accounting for $36.65 \%$ of total production, were American-owned. See RuLE OF LAw 13. 
phobia" persisted, largely because of the open support accorded Cuban caudillo Fulgencio Batista by both official and private American representatives. Given Batista's legacy of corruption and repression, the initial acclaim accorded Fidel Castro and his antipathy to the United States were to be expected. Promising true independence and the restoration of dignity and integrity to Cuban public life, his regime "constitutes so far the most determined effort to break up that community of political, economic and cultural interests which has been fostered by Cuba's physical proximity to the United States." 41

It is in this light that the acts and events which culminated in Cuba's seizure of C.A.V. and other American enterprises must be appraised. For it is clear that any significant Cuban reform necessarily required profound disruption of past patterns, including the limitation of foreign economic and political influence. ${ }^{42}$ As part of the worldwide "revolution of rising expectations" and as a manifestation of historic Latin American resentment against United States hegemony, it is perhaps inevitable that the Cuban Revolution has resulted in fundamental assaults, justifiable and otherwise, upon traditional Western notions about private property, intensely represented by past American presence in Guba. This complex background, crystallized in Banco Nacional, must be given special emphasis by our domestic courts if they are to play a positive role in the international legal process and if fundamental community policies at stake in the Law of State Responsibility are to be realistically discerned.

\section{Community Policies at Stake}

Traditionally, the Law of State Responsibility has purported to accommodate two distinct interests: the exclusive interest of each State in exercising formal authority and effective control over all property within its territorial competence, and the exclusive interest of the foreign investor in gaining access to any of the world's economic resources and in being assured maximum security upon the achievement of that end. On the one hand, States have long insisted upon the right to order and structure their economies in unhampered freedom, whether through exercise of the power to deprive absolutely or through application of such regulatory powers as the police power and the power to tax. ${ }^{43}$ Commonly

41 Id. at 9.

42 José Martí, acknowledged by Fidel Castro as the intellectual progenitor of the 26th of July Movement, was a Cuban patriot who helped lead the final revolt against Spain in 1895. In his voluminous writings Marti stated that a nation dependent upon a monocultural export economy would not long remain free. He therefore urged agricultural diversification lest United States dominance of the sugar industry impair Cuban political sovereignty. See Grey, José Marti and Social Revolution in Cuba, $5 \mathrm{~J}$. INTER-AMERICAN STUDIES 249, 253-54 (1963).

43 Regulatory techniques may be so employed, as to constitute "creeping expropria. 
honored by such symbols as "national sovereignty," "territorial jurisdiction," "self-determination" and "nonintervention," the principle of territorial jurisdiction remains today the most basic organizing principle of world order. The exclusive competence of States, however, at least where aliens are affected, is not unbridled. The concern of the international investor for maximum access and security has thus found expression in such generalizations as "the doctrine of acquired rights," "the inviolability of private property," "the principle of nondiscrimination," "the requirement of prompt, adequate and effective compensation" and "the rule of public utility." These allegedly precise and often opposing sets of claims have evolved through several centuries of international jurisprudence. Essential to a present-day understanding of the Law of State Responsibility, therefore, is an appreciation of both its theoretical antecedents and the dichotomous nature of its development.

Its theoretical framework was conceived in a relatively static world of culturally isolated European communities governed by personal sovereigns at a time when "the law of nations" was considered part of "the universal law of nature," reflecting general agreement upon an oscillating and evolving scale of moral and economic values. Whether it was when men exorcized the specter of agrarian feudalism through appeals to doctrines of natural right, or when men glorified their commercial instincts through laissez faire notions of individual self-interest and unfettered economic freedom, or when utilitarian and humanitarian conceptions of private wealth ownership sought to alleviate the economic and social maladjustments generated by the hum of the factory engine, patterns of legal and economic expectation in the international community from the early Reformation to the mid-nineteenth century were almost wholly European in character and almost wholly shared. ${ }^{44}$ Not surprisingly, foreign property interests, such as there were, posed few problems in the international affairs of this pre-industrial world.

The practical conditions which first gave rise to the operative development of the Law of State Responsibility, on the other hand, largely describe the world arena from about 1850 to World War I.45 By and

tion" or "nibbling the foreign property owner to death." See RuBIN, Private ForeIGN INVESTMENT 43 (1956). The problem is not one of incompatibility between States' rights to exclusive control over internal wealth processes and the property interests of aliens, but one of economic adjustment and the establishment of a modus vivendi conducive to the maximization of goal-values.

44 See Clough \& Cole, Economic History of Europe chs. 4, 6-8 (3d ed. 1952); Dunn, The Protection of Nationals 45-53 (1932); Ellsworth, The International Economy ch. 2 (Rev. ed. 1958); HeILbroner, The Making of Economic Society 18-71 (1962). For a brilliant analysis of the evolution of traditional theories of individual property rights, see TAWNEY, The AcQuistrive SOcIETX (1920).

45 See Dunn, op. cit. supra note 44, at 53-61. 
large, it was during this period that private foreign investment first assumed truly international proportions. ${ }^{46}$ With the acceleration of industrialization, improvements in agricultural technology, faster means of communication and increasing number and complexity of business and financial techniques, European people, capital and predispositions, to say nothing of goods, flowed as never before until the old mercantilist structure was finally dismantled. Inevitably, the appearance of the European trader and investor in sovereign foreign lands, notably in politically independent but unstable Latin America, produced the conflicts which helped generate the prescriptions today subsumed under the Law of State Responsibility.

The prescriptions which evolved, however, although of purported impartiality, are demonstrably European in origin and bias. Principles of common justice and fair dealing which had been forged in the simpler pre-industrial era (e.g., notions of the sacredness of private property and of absolute freedom of contract) were transmuted into accepted patterns of expectation in the wider international community. ${ }^{47}$ Due in no small measure to the enormous expansion of British overseas investments backed by the largest empire and the most powerful fleet in the world, these principles tended to favor the capitalist economy of nineteenth century Europe. And as long as the international community was dominated by a European system of capitalistic individualism, this bias persisted. Beginning with the sweeping transformations of the Mexican and Russian revolutions, the twentieth century offered the initial and now constant challenge to these underlying values. The Cuban Revolution and Banco Nacional have again brought these traditional conflicts into sharp focus.

The challenge cannot be met, however, by such proposals as that of the American Bar Association when commenting upon the reluctance

46 Of course, the earlier Age of Discovery and the period of colonization which followed greatly expanded European horizons. Mercantilism marked national policy, however, and this for the most part meant that private foreign investment was limited to colonial territories in which mother countries exercised formal authority and/or effective control over their own nationals.

47 See Hall, a Treatise on International Law 59-60 (8th ed. 1924); Kaplan \& KaTZENBACH, op. cit. supra note 5, at 62-70. These expectations were reflected by the end of the nineteenth century in ANzilotTr, Teoria Generale Della Responsabilitadello Stato Nel Dirtrto Internazionale (1902); Heilborn, Das System des VölkerRECHTS ENTWICKELT AUS DEN VölKERREChTLICHEN BEGRIFFen (1896); TCHERNOFF, Le DROIT de Protection Exerce par un Etat a L'Egard de ses Nationaux Residant a L'Etranger (1898); Tripel, Volkerrecht und LandesRecht (1899). See also Borchard, Diplomiatic Protection of Crrizens Abroad (1961), which demonstrated the extent to which the Law of State Responsibility had become a unified body of doctrine within the Western world. 
of the court of appeals to categorically impose a nineteenth century compensation standard:

No consideration appears to have been given by the court to the possibility of excluding foreign-owned property in such "large-scale measures" so that questions of international responsibility would not arise. ${ }^{48}$

Clearly, this solution is that of the proverbial ostrich. Nationalistic fervor desires to eradicate remnants of colonial pasts, and pressures for socioeconomic and political reform cannot be so summarily dismissed and it is preposterous to assume that developing nations can be persuaded by such unrealistic proposals. The Bar Association might more profitably have recognized that divergent methods of achieving fundamental goals are not necessarily fatal to the future of foreign investment, but may, when realistically evaluated, effectively promote security and abundance. ${ }^{49}$

Nor is the task simplified by the proposals of some less developed nations to exclude private foreign investment. There has been a disturbing unqualified acceptance recently of the view that problems of social and economic development can be resolved only by recourse to the public sector. Those who would eliminate private capital entirely, however, like those who deem private enterprise the sole panacea, are victims of a doctrinaire approach to problems of economic development. Of course, there is ample justification, as noted above, especially in the politically sensitive economic sectors of underdeveloped countries, for wide public participation in the infrastructure of national economies.50 But balanced

48 Report by the Committee on International Trade and Investament, Section of International and Comparative Law, ABA; The Protection of Private Property INVESTED ABRoAd 10 (1963).

49 The variety of modalities used to obtain compensation in the twentieth century is illustrative. Settlements have included the use of frozen assets, tying arrangements, indemnification from the profits of the seized enterprise, barter agreements and the like. See Aubert, Foreign Expropriations in Swiss Law, 6 AM. J. CoMp. L. 577 (1957); Dawson and Weston, supra note 16; Doman, Compensation for Nationalised Property in Post-War Europe, 3 INT'L L.Q. 323 (1950); Drucker, The Nationalization of United Nations Property in Europe, 36 Transact. Grot. Soc'y 75 (1957); Farmanfarma, The Oil Agreement Between Iran and the Internaiional Oil Consortium: The Law Controlling, 34 TExAs L. REv. 259 (1955); Rubin, Nationalization and Compensation: $A$ Comparative Approach, 17 U. CHI. L. REv. 458 (1950); Ujlaki, Compensation for the Nationalization of American-Owned Property in Bulgaria, Hungary and Rumania, 1 N.Y.L.F. 265 (1955). A more recent and interesting development occurred in Brazil, whereby the Brazilian Government has agreed to provide deprived American telephone companies with a high rate of compensation on the condition that they reinvest the same in less politically sensitive sectors of the national economy. See N.Y. Times, April 13, 1962, p. 1, col. 4 (late city ed.); Wall Street Journal, February 1, 1963, p. 4, col. 3 (Midwest ed.).

50 Thus, nations may not wish to have their communication, transportation and 
economic growth will not be attained without encouraging private as well as public participation in the economic superstructure of a nation, 51 if only because public funds are not sufficient to meet these needs. ${ }^{52}$ In addition, private capital can help offset the diversion of limited technical funds and know-how from priority development programs. It can contribute substantially to the growth of individual technological and administrative skills. It can foster new markets for related infant industries. And, given wise administration, private capital can assure economically efficient enterprises central to the national well being.

Recognizing the need for both socio-economic reform and private foreign investment, therefore, it should be clear that what is at stake apropos the Law of State Responsibility is the freedom of economic initiative, experiment and diversity on the one hand, and the assurance of economic security, stability and cooperation on the other. In the most abstract sense, the viability of the Law of State Responsibility itself is at stake. For the strength of any legal system, especially one characterized by the absence of an effective supranational regulatory authority and marked by the lawless threat of nuclear destruction, necessarily depends upon the extent to which the common interest of all its participants in assuring the peaceful shaping and sharing of the world's economic resources is kept at the forefront of the decision making process.

This common interest, which may be defined generally as the establishment and maintenance of an appropriate balance between the exclusive interests of individual States, is dependent upon the effectiveness of and respect for the Law of State Responsibility. In this revolutionary era, however, effectiveness and respect themselves depend in turn upon a creative, equitable and efficient balance between demands for both socioeconomic reform and private profit. Because of complex contemporary interdependencies, that balance will be creative only to the extent that the economic goal-values of each nation can be maximized without un-

other public utilities controlled or owned by aliens. Similarly, as took place in Mexico in the 1920-30s, basic natural resources are often regarded as properly subject to State control in the interest of national security. In this connection, see Bronfenbrenner, supra note 24. For a comprehensive treatment of the Mexican nationalizations see Kunz, The Mexican Expropriations, 17 N.Y.U.L.Q. 327 (1940).

51 This includes areas of manufacture, supply and distribution in which aliens from wealthier nations may have more technical skill and experience. Discussions of this thesis may be found in such recent commentaries as BAUER \& YAMEY, ThE EcoNomics of Under-Developed Countries 142-45 (1957); Mason, Economic Planning: Government and Business in Economic Development (1958); Timberg, The Shaping OF THE WorLd Economy ch. 7 (1962); The United Nations Development Decade, U.N. Doc. No. E/3613, ch. 6 (1962); Collado, Economic Development Through Private Enterprise, 41 For. AFr. 708 (1963); Gardner, International Measures for the Promotion and Protection of Foreign Investment, 9 J. PuB. L. 176 (1960).

52 See Gardner, supra note 51, at 178; Collado, supra note 51, at 714. 
duly thwarting the economic aspirations of others. It will be equitable only insofar as it can preserve freedom from arbitrary decisions based upon exclusive national and cultural preferences. And it will be efficient only to the degree that it can secure a minimum waste of investment in time, energy and resource. It is the establishment and maintenance of this balance which restricts exclusive claims to the minimum reasonably necessary to secure the special interests asserted and which promotes to the highest possible degree the inclusive interest of the entire world community in maintaining and encouraging a constant and productive flow of wealth across State boundaries. As eloquently stated by a past president of the American Society of International Law:

The most rational alternative open to peoples who genuinely project a world public order of human dignity would accordingly appear to be, not futilely to attempt to repel the advance of more inclusive decision, but rather to continue to seek that balance between the inclusive competence of the general community of states and the exclusive competence of particular states most economically designed to further their long-term basic goal values. ${ }^{53}$

In short, it is the establishment and maintenance of this balance which is in the common interest of all peoples everywhere and which therefore must be the prime policy consideration applied to the familiar decision making task of securing an accommodation and reconciliation of conflicting claims arising under the Law of State Responsibility. It cannot be applied without intelligence, impartiality and creative imagination.

\section{The Outcome of Decision Appraised}

We have attempted to identify the claimants and their objectives, to explore the context within which Banco Nacional arose and to project the fundamental community policies which are at stake. We turn next to the decisions themselves.

In the months preceding the district court decision, United StatesCuban relations steadily deteriorated. Among the disruptive events were the summary proceedings of the Cuban revolutionary courts, the passage of Cuba's agrarian and urban reform laws, the visit to Havana of Soviet Deputy Premier Anastas Mikoyan, the suspension of the Cuban sugar quota, the seizure of American and other foreign enterprises and the abrupt dismissal of members of the Cuban judiciary. On January 3, 1961, the United States severed diplomatic and consular relations. Nearly four months later, on March 31, after further recriminatory exchange be-

53 McDougal, Studies in World Public Order 233 (1960). 
tween the two nations and the formation in Florida of the exile Revolutionary Council, the district court rendered its decision.

Between the time of this decision and that of the court of appeals on July 6, 1962, tensions heightened. It was during this period that Cuban exiles, with United States support, mounted the abortive Bay of Pigs invasion. In addition, Cuba was proclaimed a socialist state, popular elections were rejected, private educational facilities were nationalized, Premier Castro proclaimed himself a Marxist-Leninist, the O.A.S. expelled Cuba from membership, the United States imposed a trade embargo and Soviet military and economic aid poured into the island.

It is against this immediate setting ${ }^{54}$ and the general context within which Banco Nacional arose that both decisions must be assessed. No decision can be realistically appraised without exposing all of the factors which, acknowledged or not, necessarily condition its outcome.

While the district court held that it was not free "to refuse enforcement to the nationalization decree because it violates the public policy of the forum," 55 the court ruled that it could examine the international validity of Law No. 851 pursuant to which G.A.V. was nationalized, the Act of State Doctrine notwithstanding. If Cuba had violated international law, the court reasoned, her agent, Banco Nacional, would have no title to the sugar proceeds in question. After so finding, the court dismissed Banco Nacional's complaint. The decision was based on the following: (1) The seizure of C.A.V. "was not reasonably related to a public purpose"; 56 (2) the nationalization measure was of a "discriminatory nature"; 57 and (3) the nationalization decree "[did] not provide adequate compensation for the taking of the properties." 58

Upholding the district court's refusal to invoke the Act of State Doctrine, the court of appeals declined "to attempt a resolution of [the] difficult question" of "whether a government's failure, in and of itself, to pay adequate compensation for the property it takes is a breach of international responsibility." 59 Nevertheless, this court found Cuba in breach of international law because

the Cuban decree of expropriation not only failed to provide adequate compensation but also involved a retaliatory purpose and a discrimination against United States nationals . . . 60

54 See generally, Rule of LAw, op. cit. supra note 37, at 5-7; Reeves, The Cuban Situation: The Political and Economic Relations of the United States and Cuba, 17 Bus. LAw. 980 (1962); N.Y. Times, March 1, 1959 through July 6, 1962.

55193 F. Supp. at 379-80.

56 Id. at 384 .

57 Id. at 385.

58 Ibid.

59 307 F.2d at 864 .

60 Id. at 868. 
Accordingly, the court of appeals ruled that Banco Nacional had no claim to the proceeds held in receivership and affirmed dismissal of the complaint.

A careful analysis of these opinions reveals that both tend to obfuscate, rather than clarify, the function and requirements of the Law of State Responsibility. If left unappraised, they may seriously mislead both future claimants and decision makers who seek in them those predictable guidelines for future decision which assure that stability of economic expectation vital to international investors and developing nations alike.

\section{A. The Claim of Public Utility}

Traditional doctrine insists that the private property of aliens may be taken only for a public purpose. ${ }^{61}$ Absent such purpose, it is said, a foreign wealth deprivation violates international law. ${ }^{62}$

The district court unequivocally embraced this orthodox "rule." Thus, Judge Dimock held:

The taking was avowedly in retaliation for acts by the Government of the United States, and was totally unconnected with the subsequent use of the property being nationalized. This fact alone is sufficient to render the taking violative of international law. ${ }^{63}$

The court of appeals, however, declined to apply the public utility doctrine with such finality. Unwilling to concede that absence of a public purpose alone constitutes a violation of international law, the court found that "confiscation without compensation when the expropriation is an act of reprisal [i.e., not of public utility] does not have significant support among disinterested international law commentators from any country"64 to merit legal validity. It followed, therefore, that Cuba had committed a "prima facie breach of international law" because "peacetime seizure of the property of nationals of a particular country, as an act of reprisal against that country, appears to this court to be contrary

61 The terms "public utility," "public benefit" and "public necessity" have also been used. The United Nations has given the concept a wide and general interpretation in Paragraph I (4) of its Resolution 1803 (XVII) on Permanent Sovereignty Over Natural Wealth and Resources: "Nationalization, expropriation or requisitioning shall be based on grounds or reasons of public utility, security or the national interest which are recognized as overriding purely individual or private interests, both domestic and foreign." Quoted in 18 N.Y.C. BAR Ass'N RrCoRD 377, 395 (1963).

62 See White, op. cit. supra note 23, at 5-6, 145-50; WorTLEY, EXProprLatron IN Public INTERNational. LAw 115-16 (1959); Cheng, Expropriation In International Law, 21 SoL. 98, 99 (1954); McNair, The Seizure of Property and Enterprises in Indonesia, 6 NETHERLANDS INT'L L. REv. 218, 243 (1959).

63193 F. Supp. at 384-85.

64307 F.2d at 866 . 
to generally accepted principles of morality throughout the world." 65 The court thus linked public utility to the principle of compensation. In support of the court's finding, however, Judge Waterman quoted the identical language cited by the district court for the "rule" of public utility. ${ }^{66}$ Inferentially, if not expressly, therefore, the court of appeals perpetuated this orthodoxy.

The doctrine of public utility is not new. Early declared by Grotius to be one of several limitations upon a sovereign's right of eminent domain, ${ }^{67}$ the doctrine was incorporated into the legal systems of all of the major eighteenth and nineteenth century powers in order to protect against domestic executive and legislative abuse of private property rights. ${ }^{68}$ Some countries, significantly the United States, have since interpreted this essentially domestic legal concept as an independent "rule" of customary international law for determining the legality of foreign wealth deprivations. ${ }^{69}$

Notwithstanding the positions of the district court and the court of appeals--positions, incidentally, which largely reflect United States Government policy preferences70_it is today clear that the "rule" of public utility is of little or no value for the Law of State Responsibility. Not only may its authoritativeness be questioned, but it is ambiguous in definition and nonfunctional in practice. Even its proponents question its practical effectiveness. ${ }^{71}$

65 Ibid.

66 Compare 307 F.2d at 866, with 193 F. Supp. at 384, n.22.

67 Grotius, ON the Rights of War and PeAce 179 (Whewell transl. 1853). Pufendorf also upheld this view but failed to define the abstraction beyond pointing out that the "necessity" which would justify a taking need not always be considered in the sense of "emergency." DRoIr dE LA NATURE ET DES GENS 1286 [Classics of International Law ed. 1954].

68 See White, Nationalisation of Foreign Property 146 (1961).

69 This development has been exemplified by United States efforts to include a "public purpose" clause in treaties of friendship, commerce and navigation. See WILson, United States Commercial Treaties and International Law 120-21 (1960); Walker, Treaties for the Encouragement and Protection of Foreign Investment: Present United States Practice, 5 AM. J. CoMp. L. 229 (1956). Metzger, however, has stated that the public purpose doctrine is not "an international law requirement." Metzger, Multilateral Conventions for the Protection of Private Foreign Investments, 9 J. PuB. L. 133, 140 (1960).

70 In 1938, Secretary of State Cordell Hull, in a Note to the Mexican Ambassador, acknowledged the "sovereign right of any government to expropriate private property within its borders in furtherance of public purposes [provided compensation is paid]." Quoted in Briggs, The LAW of NATIONs 556 (2d ed. 1952). More recently, in its Note of July 16, 1960 to the Cuban government, the United States severely criticized Cuban Law No. 851 as retaliatory and, hence, unrelated to a public purpose. 43 DEP'T STATE BuLr. 171 (1960).

71 Thus, Restatement, Foreign Relations Law of the United States, \& 190, comment b (Proposed Official Draft, 1962), states: "Although the requirement of a public 
What constitutes a "public purpose" in customary international law? The conspicuous paucity of precise scholarly comment on this question is undoubtedly due in great measure to the normative ambiguity of the concept. Rarely discussed by international tribunals, ${ }^{72}$ it is most frequently invoked by domestic courts adjudicating claims to the so-called "police power" and the power of "eminent domain" in cases involving local property deprivations. ${ }^{73}$ As might be expected, the concept is thus defined less with regard to the diverse expectations of the world community than in terms of the perspectives of Western decision makers ${ }^{74}$ their value preferences, their identifications and their expectations of future events-easily traced to eighteenth and nineteenth century capitalistic utilitarian notions of private property.

Perhaps it is not surprising, therefore, that despite the wording of Paragraph Third of Cuban Executive Power Resolution No. 1 (which declared that "these compulsory expropriations are carried out for the reasons of public necessity and national interest . . .."75), the district court concluded:

The taking of the property was not justified by Cuba on the ground that the state required the property for some legitimate purpose or that transfer of ownership of the property was necessary for the security, defense or social good of the state. ${ }^{76}$

Although not subscribing to the traditional "rule" of public utility, the

purpose is frequently referred to in international jurisprudence, as well as in the constitutions of many states, there is little authority in international law establishing any useful criteria by which a state's own determination of public purpose can be questioned." To similar effect, see Domke, Foreign Nationalizations: Some Aspects of Contemporary International Law, 55 AM. J. INT'L I. 585, 590-91 (1961); Sohn \& Baxter, Responsibility of States for Injuries to the Economic Interests of Aliens, 55 AM. J. INT'L L. 545, 555 (1961) (comment on Draft Convention on the International Responsibility of States for Injuries to Aliens).

72 In the Walter Fletcher Smith Claim (United States/Cuba), 2 U.N. Rep. Int'l Arb. Awards 913 (1929), the arbitrator found that "the expropriation proceedings were not, in good faith, for the purpose of public utility." To the same effect, see Oscar Chinn Case, P.C.I.J., ser. A/B, No. 63, at 75 (1934); El Triunfo Case (United States/El Salvador), For. Rel. of U.S. 838 (1902); The Savage Claim (United States/El Salvador), 2 Moore, Arbirrations 1865 (1893). In none of these cases was the concept explored. Moreover, none turned on the lack of "public utility" alone.

73 The experience of our own courts is illustrative. See McDougal \& HABER, Property, Wealth, land: Allocation, Planning and Development 83.94 (1948); Cribbet, FrITZ \& Johnson, Gases ON Property 1065-1118 (1960).

74 It is submitted that, notwithstanding European influence in the nineteenth century, Latin American perspectives may be considered non-Western. E.g., DEAN, THE NATURE OF THE NON-WESTERN WORLD (1957).

75193 F. Supp. at 383 , n.14.

$70 \mathrm{Id}$. at 384 . While willing to search for evidence of "retaliation" in the language of the decree, Judge Dimock was apparently indisposed to acknowledge an express assertion of public purpose. 
court of appeals, like the court below, found no public purpose in the taking. ${ }^{77}$ It found, instead, a "retaliatory purpose."

In erroneously posing retaliation as the antithesis of public purpose, both courts unnecessarily confused an already ambiguous abstraction. While a retaliatory seizure may in fact be undertaken for purely private and selfish motives, there is no inevitable nexus between the two notions; presence of retaliation need not mean absence of public purpose. It is wholly possible, even given a retaliatory motive, that property may also be taken "for the security, defense or social good of the state."78 An impartial appraisal of the factual context of Banco Nacional makes this clear. Moreover, had the Cuban seizure not been retaliatory, either avowedly or in fact, would the courts still have found no public purpose? Given an otherwise identical set of facts, we think this hardly possible. Perhaps the presence or absence of retaliation may help determine whether or not a seizure is discriminatory, ${ }^{79}$ but we fail to see its relevance in determining the existence or nonexistence of a public purpose. Any operative conjunction between the two concepts is entirely fortuitous. With all due respect it is submitted that national and cultural identifications placed a disproportionate premium upon the "rule." The district court's neglect of Paragraph Third thus produced what one commentator has called a decision which "artificially denies a public purpose because the particular expropriation was decreed as a response to the American cut in the Cuban sugar quota."80 For its part, the court of appeals would have been far wiser to abandon the doctrine of public utility altogether, rather than further press compliance with its inherently subjective presumptions.

Moreover, the "rule" of public utility today serves little function in clarifying complex issues and available policy alternatives. Given a modicum of authentic information about the revolutionary world in which we live, the incompatibility of this norm with the context of Banco Nacional is clear. Where the "rule" may once have had authoritative value, as in pre-1914 limited foreign wealth deprivations, today the entrance of government into the once exclusive preserves of private enterprise and its assumption of greater responsibility for individual welfare renders the public purpose doctrine meaningless, if not obsolete.

77307 F.2d at 868 .

78 Indeed, it is arguable that the public purpose of the measure is intensified since States do not retaliate without deeming their national security or interest at stake.

79 Section 205 of the RESTATEMENT, op. cit. supra note 71, links retaliation with discrimination. This questionable relation is discussed infra, at p. 91.

80 Falk, Toward a Theory of the Participation of Domestic Courts in the International Legal Order: A Critique of Banco Nacional de Cuba $v$. Sabbatino, 16 RuTGERS L. REv. 1, 38 (1961). 
A realistic analysis of contemporary extensive foreign wealth deprivations makes clear that such seizures are prima facie acts of public utility, designed to play a substantial role in changing the character of societies the world over. Indeed, the very definition and derivation of such words and expressions as "socialization," "nationalization" or "the redistribution of wealth" (each of which describe the events which have occurred in Cuba) presume a public purpose. As Gillian White has noted:

The classic notion of expropriation for public utility purposes is only meaningful in the context of a legal system which is based on respect for private property .... Such a context is no longer common to all the members of the international society, and in these circumstances it is doubted whether the retention of the public utility principle would serve much purpose either in the clarification of the complex issues raised by the nationalisation of alien property, or in preventing the occurrence of disputes over such measures. ${ }^{81}$

Moreover, the nonfunctional character of the "rule" of public utility becomes obvious when projected against the goals of a viable Law of State Responsibility. It is significant that, to our best knowledge, no compensation has ever been awarded where absence of a public purpose has alone been the determinant of illegality. ${ }^{82}$ The existence of the "rule" offers scant assistance to the alien investor seeking reparation for his loss. It makes little financial difference to investors whether their property is seized for reasons of public utility or for any other purpose. Of course, it can be argued that the concept should be preserved to justify punitive damages as a deterrent to State action. International decision makers, however, have traditionally been reluctant to grant such damages, or at least to so label them. ${ }^{83}$ To invoke a theory of punitive damages to justify retention of the "rule" of public utility flaunts contemporary convictions about national sovereignty and, in effect, denigrates the legitimate right of States to order and structure their economies as they see fit. This is especially futile in extensive foreign wealth deprivations where high degrees of national sensibility are involved. Traditionally conceived, compensatory damages would seem sufficient to meet deterrent demands.

It may be questioned, therefore, whether the "rule" of public utility,

81 Whrte, op. cit. supra note 68 , at 149.

82 See id. at 150 .

83 Punitive damages are awarded most often in cases involving outrageous denials of procedural justice or in international delicts of a quasi-criminal nature. Moreover, since all international damage awards stem from notions of both reparation and deterrence, it is difficult, if not impossible, to isolate one fiction of damages from another. This observation is discussed in DuNN, op. cit. supra note 44, at 172-87. 
as invoked and applied by the district court and the court of appeals, is consistent with the commonplace observation of a world of diverse public orders and whether it is, in fact, adequate to meet contemporary needs. The courts would have better served the cause of the Law of State Responsibility had they directly attacked its inherent ambiguity and non-functionality. Continued exhortations about the "rule" serve only to raise and frustrate unwarranted expectations. The "rule" does nothing to restrict exclusive claims to the minimum reasonably necessary to secure the special interests asserted and to promote to the highest possible degree the inclusive interest of all States in encouraging a constant and productive flow of wealth across State boundaries. Its principal effect is to impose eighteenth and nineteenth century European cultural preferences upon what Professor Falk has called questions of "legitimate diversity" between existing public orders ${ }^{84}$ and to divert the focus of responsible attention from fundamental community policies. ${ }^{85}$ The district court and the court of appeals thus improperly relied upon the "rule" of public utility in dismissing plaintiff-appellant's complaint.

\section{B. The Glaim of Nondiscrimination}

Commentary and practice provide abundant evidence that a State may not discriminate against the person or property of an alien without violating international law. 86 Both courts reaffirmed this "rule" in Banco Nacional.

Traditionally, nondiscrimination in international law means that aliens must be assured at least the same, if not better, protection as municipal law confers upon the nationals of a foreign State..$^{87}$ As implied, there are two schools of thought. Proponents of the "standard of equal [i.e., national] treatment" insist that customary international law "does not ... recognize the right to claim for the foreigner more favourable treatment than is accorded to nationals." 88 Advocates of the heretofore more widely accepted "minimum [i.e., international] standard of justice," however,

84 Falk, supra note 80 , at 34-35.

85 At least one commentator, while disapproving of a "rule" of public utility, believes that the concept may be useful in defining nationalization "and in distinguishing it from other forms of State interference with private property such as penal confiscation or acquisition for purposes of security and defence." WHITE, op. cit. supra note 68, at 148 .

86 The principle was early enunciated by Vattel in 1765. VATTEL, The LAw of Natrons 165 (ed. 1872). Recent widespread demands for civil and other human rights, in the United Nations and elsewhere, are testimony to the continued vitality of this principle.

87 See Wrrre, op. cit. supra note 68, at 119.

88 Guerrero, Report on the Responsibility of States for Damage Done in Their Territories to the Person or Property of Foreigners, 20 AM. J. INT'L L. Supp. 176, 182 (1926). 
demand more. The treatment due aliens, they contend, is wholly independent of the treatment given nationals. .9 $^{9}$ Under either standard, however, it is clear that the difference in the actual treatment accorded aliens and nationals, not the motives which precipitate State acts, is the determinant of discrimination. As stated by the Permanent Court of International Justice in the Oscar Chinn Case (1934):

The form of discrimination which is forbidden is . . discrimination based upon nationality and involving differential treatment by reason of their nationality as between persons belonging to different national groups. ${ }^{90}$

\section{This point must be remembered when analyzing Banco Nacional.}

The district court responded to the seizure of C.A.V. as follows:

$[\mathrm{T}]$ he present nationalization measure is contrary to the standards of international law because of its discriminatory nature. The act [Law No. 851] classifies United States nationals separately from all other nationals, and provides no reasonable basis for such a classification. The decree does not justify the classification on the basis of the conduct of the owners in managing and exploiting their properties or on the basis of their importance to the security of the state where ownership of the property resides. The justification is simply reprisal against another government. 91

89 The most frequently cited expression of the international standard of justice is that of former Secretary of State Elihu Root: "There is a standard of justice, very simple, very fundamental, and of such general acceptance by all civilized countries as to form a part of the international law of the world. The condition upon which any country is entitled to measure the justice due from it to an alien by the justice which it accords to its citizens is that its system of law and administration shall conform to this general standard. If any country's system of law and administration does not conform to that standard, although the people of the country may be content or compelled to live under it, no other country can be compelled to accept it as furnishing a satisfactory measure of treatment to its citizens." The Basis of Protection to Citizens Residing Abroad, 4 Procendings Am. Soc'y INT'L L. 16, 21 (1910).

90 P.C.I.J., ser. A/B, No. 63, at 87 (1934). (Emphasis added.) See also British Claims in the Spanish Zone of Morocco, 2 U.N. Rep. Int'l Arb. Awards 615, 647 (1923) (Author's transl.), in which the arbitrator stated: "It can be considered settled that in International Law a foreigner may not be deprived of his property without fair indemnity, subject, of course, to any treaties in force; that is especially true when restriction of property rights is the result of a measure directed against certain individuals and not against all owners similarly situated." See also the Case of the Norwegian Claims Against the United States, I U.N. Rep. Int'l Arb. Awards 307, 339 (1922), in which the arbitral tribunal invoked the principle against the United States, as follows: "The United States are responsible for having thus made a discriminating use of the power of eminent domain towards citizens of a friendly nation, and they are liable for the damaging action of their officials and agents towards these citizens of the Kingdom of Norway."

91193 F. Supp. at 385. (Emphasis added.) 
Reasoning that United States nationals were expressly singled out for solely retaliatory purposes, ${ }^{92}$ the district court found discrimination not because of differences in treatment between United States and Cuban citizens, but because of the motive of the legislation in question. The court neglected to inquire whether Law No. 851 and Law No. 890 (pursuant to which Cuban-owned sugar enterprises were nationalized on October 13, 1960), ${ }^{93}$ might have revealed differences in treatment between domestic and alien sugar companies. Indeed, unlike the court of appeals, Judge Dimock failed even to acknowledge the existence of Law No. 890 or any other Cuban nationalization measure. The sine qua non of the "rule" of nondiscrimination, however, is treatment, not motive. This reliance upon motive rather than treatment is underscored by the court's concluding statement on this matter:

Doubtless the measures which states may employ in their rivalries are of great variety but they do not include the taking of the property of the nationals of the rival government. ${ }^{94}$

The essence of the court's holding, therefore, was that Guba had retaliated and hence had discriminated.

While the circuit court explored more fully defendants' claim of nondiscrimination, it also failed to disentangle the concept of retaliation from the doctrine of nondiscrimination. Judge Waterman began by noting that Law No. 851 and Executive Power Resolution No. 1 "would appear to be discriminatory, since retaliation against a person's homeland is not a reasonable basis for a distinction in treatment." 95 The court then sought to meet Banco Nacional's defense: That the seizure was not discriminatory because it arose as part of Cuba's general policy "to establish socialism" by "nationalization of industrial and agricultural enterprises of size" through such measures as the Agrarian Reform Law and the Urban Reform Law. ${ }^{96}$ The court of appeals denied any relevant relation between Law No. 851 on the one hand and the agrarian and urban reform laws on the other under which, the court itself noted, "all large land holdings and multi-family dwellings were nationalized." 97 The court's sole explanation was that

these latter two pieces of legislation are of little relevance to the

92 It is possible, of course, that the specific naming of a group of aliens may only be for the purpose of identifying the property to be taken by a particular decree. We do not suggest that this was the case, however, in the Cuban legislation.

93 This relationship was noted, however, by the court of appeals at $307 \mathrm{~F} .2 \mathrm{~d}$ at 866 .

94193 F. Supp. at 385.

95307 F.2d at 866 .

96 Brief for Appellant, p. 24, Banco Nacional, 307 F.2d 845 (2d Cir. 1962).

97307 F.2d at 867 . (Emphasis added.) The laws affected aliens and nationals alike. 
present case because of the substantial differences, in both policy and effect, between the nationalization of real estate as such and the nationalization of the means of production as such. ${ }^{98}$

We fail to discern, however, these alleged "substantial differences" in either policy or effect if only because respectable opinion has seen fit to classify real estate within the economic concept of the means of production. ${ }^{99}$ The court might have more rationally maintained the irrelevancy of the agrarian and urban reform laws by noting that some authorities restrict the concept of discrimination to persons and properties "similarly situated."100 Even such a solution would have been unsatisfactory, however, because the nationalization of particular industries, as in Cuba, often occurs not in isolation but as part of comprehensive programs asserting State control over all sources of production, distribution and supply.

Nevertheless, the circuit court did concede a relationship between the seizure of Cuban-owned sugar enterprises on October 13, 1960, and the seizure of C.A.V. and twenty-five other American-owned sugar companies on August 6, 1960. The court stated that

if the ultimate effect of all the expropriations by the Castro Cuban government was to treat Cuban-owned enterprises and American-owned enterprises exactly alike, it would be difficult for this court to find discrimination against American nationals. And, perhaps, international law is not violated when equal treatment is accorded aliens and natives, regardless of the quality of treatment or the motives behind that treatment. ${ }^{101}$

Presumably not opposing the widely accepted "minimum standard of justice," the court nevertheless chose to evaluate defendants' claim of nondiscrimination by recourse to the "standard of equal treatment," traditionally favored by Latin American legal scholars. ${ }^{102}$ It was therefore

98 Ibid.

99 See, e.g., HeIlbroner, The Making of Economic Society 63 (1962).

100 See British Claims in the Spanish Zone of Morocco, 2 U.N. Rep. Int'I Arb. Awards 615 (1923); McNair, supra note 62, at 247.

101307 F.2d at 867. (Emphasis added.)

102 The Calvo Doctrine, it may be said, is one of the historical antecedents of the standard of equal treatment. In order to limit the scope of diplomatic intervention on behalf of injured nationals in Latin America, the Calvo Doctrine, developed in the late nineteenth century, proposed "that foreigners were entitled to the same kind of treatment as natives but no better, and that, so long as local institutions of justice were open to them on the same basis as to natives, there could be no basis of an international complaint." DunN, The Protection of Nationals 56 (1932). First formulated by the Argentine jurist Carlos Calvo, the doctrine was incorporated into treaties and contracts to secure alien observance of Latin American local remedies. See BorchARD, The Diplomatic Protection of Citizens Abroad 792 (1961). For an analysis of the 
incumbent upon the court to determine whether the treatment of C.A.V. was the same as that accorded Cuban nationals.

The court found a difference and, hence, inequality in treatment because of the lapse of ten weeks between the nationalization of C.A.V. on August 6,1960, and the seizure of Cuban-owned sugar enterprises on October 13, 1960. Accordingly, the court ruled that "the Cuban government discriminated against United States nationals."103 The alleged inequality, however, is not made clear. Ostensibly, the difference was one of timing. Thus, admitting that "a short lapse of time between similar provisions in the same program, standing alone, would not create discrimination," the court nevertheless insisted that "the difference in time here is quite significant." 104 But what is "quite significant" about a ten week time differential? The court might have argued that the time gap would have given Cuban nationals sufficient notice to appraise their inventories and liquidate their assets. Indeed, this is the only meaningful argument, since we see no other reason to conclude that merely because an alien's property is taken at one moment, the treatment he receives will inevitably differ from the treatment accorded a national whose property is taken ten weeks later. Yet not even this argument was mentioned. Rather, the court found inequality of treatment merely because 'this difference in ten weeks' time stems directly from the efforts of the Cuban government to retaliate against the United States and its sugar-buying policy." 105 The answer is a non sequitur. Its only possible rational interpretation is that the seizure of C.A.V. on August 6 was simply in response to United States policy, whereas the taking of Cuban-owned sugar enterprises on October 13 was not. This seems clear in view of the court's statement that

since we have held above that seizure of the assets of nationals of an unfriendly sovereign as part of a scheme of reprisal against that country is illegal under international law, it follows that a difference in treatment accorded those nationals based upon reprisal is discriminatory. ${ }^{106}$

If this interpretation is accurate, then the difference in treatment was not, in fact, one of timing. The timing argument, in short, becomes mere window dressing for the rationale that retaliation is, in and of itself, discriminatory. In fact, therefore, the court found not a difference in treatment, but a difference in motive. This, according to the court's own

several manifestations of the doctrine, see Lipstein, The Place of the Calvo Clause in International Law, 1945 BRrT. YB. INT'L L. 130.

103307 F.2d at 867.

104 Ibid.

105 Ibid.

106 Ibid. 
interpretation of the standard of equal treatment, may not be a violation of international law at all.107

Thus, both courts were in agreement: Reprisal against a State through seizure of the property of that State's nationals is ipso facto discriminatory.

It does not follow, however, that differences in treatment necessarily flow from even unlawful reprisals. The concepts of discrimination and retaliation, like those of public utility and retaliation, lack imperative relationship. As noted, discrimination conceptually involves differences in treatment, whereas reprisals connote distinctions in motive. Since the legal and economic rights and interests of the claimants in Banco Nacional were largely determined by this thinking, and because of the potential effect of these findings upon the future trend of decision, further analysis is required. Accordingly, two basic questions must be answered: (1) Cuba's avowed reprisal aside, could the courts have found discrimination against United States nationals under the "rule" of nondiscrimination? (2) If not, could the courts have found a breach of international law because of Cuba's avowed retaliation, in and of itself, under the doctrine of reprisals?

As Judge Waterman suggested, if the ultimate treatment accorded United States nationals by all the Cuban nationalization measures was not, in fact, different from that accorded Cuban citizens, notwithstanding that American properties were seized for avowedly different motives, there may have been no discrimination. Apart from its perplexing timing argument, however, the circuit court made no attempt to elaborate meaningful differences in treatment between American and Cuban sugar interests pursuant to Law No. 851 and Law No. 890, respectively; e.g., differences in compensation or procedural justice. Indeed, had either court appraised the full factual context of Banco Nacional they might have found no discrimination at all.

It is commonplace that in many if not most contemporary nationalizations, the wealth taken is often substantially or entirely owned or controlled by aliens. ${ }^{108}$ Hence, on August 6, 1960, nine of the ten and seventeen of the twenty largest sugar mills in Cuba were Americanowned or controlled. The remaining privately-owned Cuban mills represented but a small proportion of this industrial sector. ${ }^{109}$ On these

107 See note 101 supra.

108 This phenomenon may be attributed to the fact that most contemporary extensive foreign wealth deprivations are undertaken by the less developed nations of the world which for many years were subjected to intensive Western economic expansion and political penetration.

109 See Farr \& Co., Manual of Sugar Compantes 1949-50 (1950). See also Villarejo, American Investment in Cuba, NEw UNIVERSITY ThOvgkr 79-81 (Spring 1960). 
facts alone, it is arguable that there might have been no discrimination since as foreign ownership increases the likelihood of having aliens and nationals "similarly situated" between whom differences in treatment can be found decreases proportionately. ${ }^{110}$ Thus, it is noteworthy that the remaining Cuban sugar interests consisted of a sizable number of small producers. They were not, therefore, "similarly situated" with the larger American interests. At that, the Cuban interests were seized by the Castro Government less than two months later, on October 13, 1960.111 The only sugar enterprises thereafter remaining in private hands were French and Spanish owned mills controlling but 1.22 per cent of the entire industry. ${ }^{112}$ Even conceding that the existence of discrimination can be determined only by reference to persons and properties "similarly situated," it thus becomes difficult to find a discriminatory effect even within the scope of the Cuban sugar industry.

Indeed, a finding of discrimination becomes even less tenable when the entire factual context of the C.A.V. seizure is taken into account. This assumes special importance given the circuit court's emphasis on the time differential between Law No. 851 and Law No. 890. Avowedly in response to the sharp reduction of the Cuban sugar quota, Law No. 851 was nevertheless part of a program of broad social and economic reform seeking to create the revitalized Cuban society envisioned over sixty years ago by Cuban patriot José Martí. ${ }^{113}$ Beginning with the passage of the Agrarian Reform Law on May 17, 1959,114 "the first measure by the Castro régime to have any far-reaching effect on Cuba's economic structure,"115 Cuba initiated reforms affecting aliens and nationals alike. During the six month period in which C.A.V. was seized, multifamily dwellings, public utilities, other sugar companies, oil refineries, banks and trading companies were also nationalized.116 Considering that the ultimate effect of all Cuban nationalizations in all industries might

110 Carrying this to its logical conclusion, "there is as yet no rule of international Iaw which provides that a State is guilty of illegal discrimination if it nationalises alien property in a field where there are no national interests capable of being affected." Whitre, The Nationalisation of Foreign Property I44 (I961).

111 On the other hand, perhaps this relatively small time gap indicates a similarity rather than a disparity in treatment.

112 See Int'L CoMm'N of JuRists, Cuba \& The Rule of Law 13 (1962).

113 See generally, Gray, Jose Marti and Social Revolution in Cuba, 5 J. INTERAMERICAN STUDIES 249 (1963).

114 Official Gazette (June 3, 1959); Special Issue No. 7 of the Annual Series.

115 RuLE OF LAW 60.

116 Id. at 5-6, 105. See also Reeves, The Cuban Situation: The Political and Economic Relations of the United States and Cuba, 17 Bus. Law. 980, 982-85 (1962). In view of this wide-sweeping program it is arguable that C.A.V. would have eventually been nationalized in any event, with or without the impetus of the quota reduction. 
have evidenced few if any differences in treatment between aliens and nationals, ${ }^{117}$ it is lamentable that neither court felt called upon to explain the propriety of confining their inquiry to the sugar industry.

Given the uncertainty of properly finding a violation of the traditional "rule" of nondiscrimination, did Cuba breach international law by its avowed retaliation, in and of itself? Both courts appear to have so held. However, their holdings posit a questionable concept of illegality under customary international law.

The concept of nonretaliation, prior to Banco Nacional, was apparently first advanced in connection with the Indonesian seizures of Dutch property in 1958 in admitted retaliation for Dutch refusal to transfer sovereignty over West New Guinea. ${ }^{118}$ It was again posed by the Belgian delegate to the United Nations upon the seizure of Belgian properties by the United Arab Republic in 1960.119 Although the Belgian claim was not mentioned by either court, both referred to the retaliatory Indonesian nationalizations. While the district court did not define the concept, the court of appeals did so by quoting from a statement of the American Branch of the International Law Association's Committee on Nationalization of Property that "under International Law, a state may not take foreign interests as a measure of political reprisal."120 The Court then cited Section 205 of the Restatement, Foreign Relations Law of the United States, which provides in part:

When an alien is injured by conduct attributable to a state for which a state would otherwise be responsible under international law, the state is not excused from responsibility merely because its conduct is in retaliation against conduct of the state of the alien's nationality, even if the conduct of the second state is wrongful under international law.121

117 The nationalization of an entire industrial sector or, indeed, of an entire economy cannot be accomplished overnight. The Soviet nationalizations took place over a three year period. See 2 CARR, THE BolsheviK Revolution: 1917-23, 43-47, 99, 128-29 (1952). Indeed, the Mexican Revolution which began in 1910 and which involved the seizure and regulation of foreign property interests is still not at an end. In seeking to ascertain the presence or absence of discrimination, therefore, it would be more realistic at least to look to all of the known Cuban nationalizations, before and after the seizure of C.A.V., in order to ascertain the overall ultimate effect of the treatment accorded Cubans and aliens.

118 See Domke, Indonesian Nationalization Measures Before Foreign Courts, 54 AM. J. INT'L L. 305 (1960); Baade, Indonesian Nationalization Measures Before Foreign Courts-A Reply, 54 AMr. J. INT'L L. 801 (1960); McNair, The Seizure of Property and Enterprises in Indonesia, 6 NETHERLANDS INT'L L. REv. 218 (1959).

119 See Domke, Foreign Nationalizations: Some Aspects of Contemporary International Law, 55 AM. J. INT'L L. 585, 601 (1961).

120 Proceedings and Committer Reports 68 (1957-58), cited in 307 F.2d at 865.

121 Proposed Official Draft, 1962, cited in 307 F.2d at 865. 
These are the only ostensibly authoritative statements of the concept of nonretaliation known to the authors. Their authoritativeness, however, is open to question. In addition to the fact that each was drawn exclusively by United States legal scholars, both are conspicuously unsubstantiated by any established trend of decision. ${ }^{122}$ Quite likely each represents more American policy preferences than prescriptions of customary international law.

The concept of nonretaliation as applied in Banco Nacional is a questionable aberration of the doctrine of reprisals which traditionally permits otherwise unlawful responses as sanctions against prior unlawful acts. ${ }^{123}$ Historically, this doctrine refers to the private seizure of alien property in retaliation for international delicts. As Brierly has noted, it was formerly "not uncommon for a state to issue 'letters of marque' to one of its own subjects, who had met with a denial of justice in another state, authorizing him to redress the wrong for himself by forcible action, such as the seizure of property of subjects of the delinquent state."124 While such "special" reprisals are no longer generally employed in diplomatic practice, some scholars continue to restrict the doctrine solely to governmental seizure or restraint of alien property. ${ }^{225}$ The generally more accepted view, however, is to consider a reprisal as "any kind of coercive action not amounting to war whereby a state attempts to secure satisfaction from another for some wrong which the latter has committed against it."126

Highly disruptive economic strategies have thus been employed as instruments of coercive policy, extending from the most mild to the most intense, in situations short of war. There is, however, a growing legitimate skepticism as to the legality of such reprisals, especially if they are not commensurate with the precipitating delict. ${ }^{127}$ Scholarly concern,

122 The Proceedings and Committee Reports of the American Branch of the International Law Association cite no authorities for this proposition. The comment accompanying $\$ 205$ of the RESTATEMENT, while failing to cite any authority, illustrates the proposition with an example seemingly based upon the district court's decision.

123 See Briggs, The Law of Nations 957-58 (2d ed. 1952); Hindmarsh, ForGe in Peace 58 (1933); Stone, Legal Control of International Conflict 289 (1954); McDougal \&. Feliciano, International Coercion and World Public Order: The General Principles of the Law of War in MaDougal, Studies IN WORLD Public Order 237, 297305, 318-19 (1960).

124 BRIERLy, The LAW of Nations 297 (4th ed. 1949). As to early English practice see Clark, The English Practice With Regard to Reprisals by Private Persons, 27 AM. J. INT'L L. 694 (1933).

125 BRIERLY, op. cit. supra note 124.

126 Ibid.

127 The Drago Doctrine, formulated in 1902, was an early attempt to regulate reprisals by prohibiting armed intervention or territorial occupation to collect debts in South America. Today, U.N. ChARTER, art. 2, para. 4, prohibits "the threat or use 
therefore, focuses upon the reappraisal of circumstances in which reprisals may lawfully be applied to redress a wrong. A widely cited attempt is that of the German-Portuguese Arbitral Tribunal in the Naulilaa Case (1928) involving personal injuries to German nationals in Portuguese territory. ${ }^{128}$ The Tribunal posed three conditions of legitimacy: (1) The State against which the reprisal is taken must first be in breach of international law; (2) the reprisal must be "preceded by a request for redress (sommation) which has been unavailing"; and (3) there must be "a proportionality between the reprisal and the offense." Thus, the concept of nonretaliation-that notwithstanding a precipitating unlawful act, a State may not seize the property of nationals of the initially delinquent State-is a complete reversal of the traditional doctrine of reprisals. The criteria formulated in the Naulilaa Case, however, accurately restate this historic doctrine. For the most part, they also effectively fulfill the needs of a meaningful Law of State Responsibility; that is, they seek to achieve a balance between exclusive national interests.

By invoking and applying the doubtful nonretaliation concept, the courts thus repudiated the historic distinction between justifiable and unjustifiable response. This enabled them to give short shrift to Banco Nacional's defense that the C.A.V. nationalization was justified because "the United States was the first offender against international law by an attempt to coerce Cuba through the reduction of American purchases of Cuban sugar."129 Both courts flatly denied any such United States transgression. The court of appeals stated that

whether she was wise or unwise, fair or unfair, in what she did, the United States did not breach a rule of international law in deciding, for whatever reason she deemed sufficient, the sources from which she would buy her sugar. We cannot find any established principle of international jurisprudence that requires a nation to continue buying commodities from an unfriendly source. ${ }^{130}$

of force against the territorial integrity or political independence of any state ...." Article 15 of the O.A.S. Charter rejects any "form of interference or attempted threat against the personality of the State or against its political, economic or cultural elements." For comments reflecting the growing skepticism of harsh economic and other reprisals, see Drier, The Organization of American States and the Hemisphere Crisis 32 (1962); Kaplan \& Katzenbach, The Political Foundatrons of International LAw ch. 8 (1961); Schacter, The Enforcement of International Judicial and Arbitral Awards, 54 AMr. J. INT'L L. 1, 7 (1960).

128 8 Recueil des Decisions des Tribunaux Arbitraux Mixtes 409, 422-25. (English trans., in BRIGGs, op. cit. supra note 123, at 951-53.)

129307 F.2d at 866.

130 Ibid. 
Indeed, by relying upon the Restatement and the Proceedings of the American Branch of the International Law Association, the circuit court, in effect, denied the relevance of any inquiry into the legality of the sugar quota reduction.

Whether United States policy "was wise or unwise, fair or unfair," it might be considered by some as a recrudescence of that economic intervention repudiated by the United States at the Seventh PanAmerican Conference in Montevideo in 1933 and in the Buenos Aires Protocol of Non-Intervention of 1936.131 Indeed the United States' action might legitimately be deemed a violation of her existing treaty obligations. Article 15 of the Charter of the O.A.S., to which the United States and Cuba were both signatories in 1960,132 provides:

No State or group of States has the right to intervene, directly or indirectly, for any reason whatever, in the internal or external affairs of any other State. The foregoing principle prohibits not only armed force but also any other form of interference or attempted threat against the personality of the State or against its political, economic and cultural elements. ${ }^{133}$

While experts may differ on whether the United States violated the O.A.S. Charter, ${ }^{134}$ it is clear from this language that Banco Nacional's defense merited at least minimum evaluation. Given the first of the criteria formulated in the Naulilaa Case, Cuba's seizure of C.A.V. and other American sugar enterprises may have been justified.

Pursuing the rationale of the Naulilaa Case, however, it does not ap-

131 Ibid. The courts should not have so summarily dismissed Banco Nacional's allegations. They might legitimately have found that the sharp quota reduction, given the historically unique economic relation between the United States and Cuba was, perhaps, not an action which should have been so abruptly vindicated by the courts. For, in addition to threatening the entire Cuban financial structure, this exclusive action flaunted Cuban expectations of economic stability. Like any favor once granted, Cuba had come to look upon the sugar quota as her just due and her inalienable right. Considering the complex interdependencies of the world community, the United States unilateral strategy assumes questionable propriety.

132 Cuba was not expelled from the O.A.S. until January 31, 1962. RuLe of LAw 7. 1332 U.S.T. 2395; T.I.A.S. No. 2361; 119 U.N.T.S. 3. This was cited in Brief for Appellant, p. 23, Banco Nacional, 307 F.2d 845 (2d Cir. 1962).

134 Perhaps by reducing the Cuban sugar quota on July 6,1960 , the United States was reprising against Cuba, rather than vice versa, in response to the seizure of American-owned oil refineries on June 29, 1960. Threats and counterthreats concerning the sugar quota had been passing back and forth between Washington and Havana before this time. On June 28, Fidel Castro threatened to seize all American property if the quota was reduced. Moreover, perhaps the United States was reprising against seizures of American property under the Cuban Agrarian Reform Law. Thus, appellant correctly stated that "there is considerable doubt as to who was retaliating against whom in the summer of 1960." Brief for Appellant, p. 22, Banco Nacional, 307 F.2d 845 (2d Cir. 1962). 
pear that Cuba attempted to obtain redress by less coercive means. ${ }^{135}$ This is suggested by the seizure of C.A.V. on the same day the United States reduced the sugar quota. Of course, it may be too optimistic to have expected a moderate Cuban reaction considering the hostility then pervading United States-Cuban relations, the importance of sugar to the Cuban economy, and a background of over a half-century of deeply resented United States economic, if not political, hegemony. Indeed, since reprisals are generally employed in contexts of varying degrees of hostility, it is questionable if a requirement of good faith subsequent protest can realistically serve as the ratio decidendi of any decision. If this be so, the courts should then have pursued the third criterion of the Naulilaa Case by inquiring into the "proportionality" between the Cuban seizures and the possible initial breach of international law by the United States.

This, of course, is a matter about which reasonable men may differ. While it may have been improper, if not unlawful, for Cuba to have effected a strategy of severe economic reprisal which by-passed alternative orderly processes of decision, it is not advisable to reject such sanctions as last resort strategies to achieve law-conforming behavior. As McDougal and Feliciano have noted, "it is a mistake to regard the doctrine of reprisals as a denial of law or of the possibility of law."136 Absent an authoritative international policing mechanism, compliance with international law depends upon mutual expectations of reciprocity and restraint which, over time, assure a creative, equitable and efficient balance of exclusive national interests. Hence, lest disproportionate response rupture economic interaction, if not imperil human survival itself, ${ }^{137}$ the principal challenge today is to vindicate those coercive strategies which both acknowledge the limitations of existing structures of authority and simultaneously insure at least minimum security in a tense and ideologically cloven world.

Of course, with the development and proliferation of techniques of mass destruction, it may be necessary to invent new principles and procedures which can effectively minimize resort to highly coercive strategies. It is suggested, however, that the district court and the court of appeals need not have discarded a practicable regulatory formula in favor of a concept of clearly dubious origin. Had the courts inquired

135 Such less coercive strategies as appeals to the United Nations, the O.A.S., or the International Court of Justice were apparently not employed.

136 McDougal \&: Feliciano, supra note 123, at 318.

137 In this connection, Cuba may be a case in point. While the unresolved property seizures were perhaps not the principal cause of United States-Cuban hostilities, they nonetheless supplemented those existing tensions which in their totality almost brought the world to the brink of nuclear war. 
into a possible disproportionality between the United States action and the Cuban reaction, their opinions would have been more persuasive and less open to theoretical challenge. The courts' inability to adjudicate the conflicting claims relating to discrimination without resorting to the questionable nonretaliation concept, therefore, suggests that they may have been "apologists for national policies determined by political arms of government."138 Moreover, their overly optimistic equation of discrimination with retaliation did little to define the actual differences in treatment accorded United States and Cuban citizens. Had they realistically appraised the factual context of Banco Nacional by focusing upon the time-honored and functional doctrines of nondiscrimination and reprisals, the expectations of future claimants might have been assured greater stability. At the same time, the courts would have clarified the common interest of the world community in achieving an economic balance between conflicting claims for freedom, safety and abundance.

\section{The Claim of Compensation}

We come finally to the issue in Banco Nacional which assumes the most decisive role in the Law of State Responsibility. Its ultimate resolution is also the only aspect of the case with which the authors are in substantial but not unreserved agreement with the courts.

Noteworthy is the lack of any express statement in either opinion that customary international law requires payment of "prompt, adequate and effective" compensation for nationalized property. To the limited extent that future claimants may be dissuaded from undue reliance upon this orthodox compensatory standard, this apparent omission may prove beneficial, for the standard has had limited utility in the post-1914 era. Accordingly, it "must not be regarded as a technical rule for the assessment of compensation." 139 At most, the "rule" is "little more than a preference assumed for bargaining purposes" to which claimants pay ritualistic tribute in seeking to maximize their goal-values. ${ }^{140}$ This observation is abundantly borne out by the practice of States in negotiating global settlements. ${ }^{141}$ Those who contend that "such practice [global compensation agreements] does not amount to a new trend, much less to an abrogation of the existing customary international law, but rather

138 KAPLAN \& KATZENBach, op. cit. supra note 127, at 270.

139 WrrTe, op. cit. supra note 110, at 243.

140 Dawson and Weston, Prompt, Adequate and Effective: $A$ Universal Standard of Compensation?, 30 FordhaM L. Rev. 727, 757 (1962).

141 Id. at 740-49; WHITE, op. cit. supra note 110, ch. 11. While nations representing their deprived nationals may begin negotiating with demands for prompt, adequate and effective compensation, the final settlement generally reflects compromise and adjustment. 
to a compromise in a given situation," 142 perpetuate a parochial view of international law. This is not to suggest, however, that the principle of compensation is itself seriously challenged. Rather, contemporary debate seeks to resolve how the timing, amount and form of compensation may be realistically determined in the twentieth century context of extensive foreign wealth deprivations. ${ }^{143}$

Law No. 851 proferred compensation in thirty-year Cuban Government bonds at a minimum two per cent interest per year. Neither court expressly criticized in theory either the timing (i.e., the promptness) or the form (i.e., the effectiveness) of this plan. They were properly critical, however, of attendant factual conditions which necessarily determined its adequacy. Thus, both the interest payable on, and the ultimate redemption of, the bonds were to be financed out of a specially segregated fund derived from twenty-five per cent of the annual foreign exchange received by Cuba from United States sugar sales exceeding three million Spanish long tons at not less than 5.75 cents per English pound of raw sugar. The courts found the scheme faulty for three reasons: ${ }^{144}$ (1) The sugar quota reduction made any sales to the United States unlikely, if not impossible; (2) between 1950 and 1959, prior to the quota reduction, the average monthly price for Cuban raw sugar shipments to the United States never exceeded 5.50 cents per English pound; and (3) in only one year from 1950 through 1959, and in only three years from 1934 through 1959, did United States sugar purchases exceed three

142 Domke, supra note 119 , at 609. See also Lillich, INTERnational Claims: TheIR Adjudication bX National Commissions 104-16 (1962).

143 The "rule" of "prompt, adequate and effective" compensation evolved during the nineteenth century as a standard by which aliens sought reparation for lost property. "Prompt" meant that compensation should be paid at the time of, if not before, the taking; "adequate" meant that the compensation should equal the true market value of the property; and "effective" meant that the indemnity should be paid in a currency usable to the alien, preferably his own. The "rule" apparently was first invoked in an extensive foreign wealth deprivation context during the aftermath of the Mexican Revolution. In practice, despite its repeated invocation, prompt, adequate and effective compensation has never been paid in an extensive deprivation. Few States could afford to restructure their economies if its strictures were faithfully observed. Insistence upon the "rule" flies in the face of twentieth century realities and is foredoomed to failure. See Dawson and Weston, supra note 140. See also WhIrE, op. cit. supra note 110 , ch. 11 . None of the alternate compensation techniques, however, including global settlements, has been entirely satisfactory to deprived alien owners. Commenting upon this fact one writer has observed: "One need only look to Cuba to see that international claims law has become a billion dollar business. This recent proliferation of claims, coupled with the reasonable expectation that the United States-Cuban experience soon may be repeated elsewhere in one or more of the so-called newer nations, has generated renewed interest in the study of various methods of peaceably resolving such disputes." Lillich, op. cit. supra note 142, at 1 .

144 The following facts may be found in $193 \mathrm{~F}$. Supp. at $385-86 \& \mathrm{n} .28 ; 307 \mathrm{~F} .2 \mathrm{~d}$ at 862. 
million Spanish long tons. Realistically examined, these conditions made any compensation, even assuming resumption of United States sugar purchases, highly improbable.

Noting these circumstances, the district court categorically held that "clearly, this is not adequate compensation within the requirements of international law."145 The circuit court, however, although acknowledging the "illusory" nature of the proposed compensation,,146 expressly declined to rule that, "a government's failure, in and of itself, to pay adequate compensation for the property it takes is a breach of international responsibility . . . "147 In addition, both courts disapproved provisions pledging vague assurances of unilateral Cuban valuation of the properties seized. ${ }^{148}$

Theoretical arguments aside, there can be little objection to the district court's finding that the surrounding conditions rendered the proffered compensation meaningless. Neither can the circuit court be criticized for calling the indemnity "illusory." Clearly, Cuba not only failed to make a good faith offer of compensation, but she may also have failed to acknowledge even a duty to compensate under international law. 149 Because Cuba failed to meet even the most minimal compensatory requirements, the courts properly found that Cuba had no title to the C.A.V. property and correctly dismissed Banco Nacional's complaint.

Neither opinion, however, is beyond criticism. By neglecting to define "adequate compensation," Judge Dimock may have encouraged perpetuation of the orthodox compensatory standard which has traditionally reflected the exclusive interests of the private investment community. Judge Waterman, on the other hand, was entirely too deferential to the exclusive demands of the less developed nations, among which Cuba is numbered.

Although the district court never referred to the terms "prompt" and

145193 F. Supp. at 386.

146307 F.2d at 862 .

147 Id. at 864 .

148193 F. Supp. at $386 ; 307$ F.2d at 862 .

149 The terms of the Cuban compensation were so unrealistic as to cast serious doubt upon Cuba's good faith willingness to compensate at all. Moreover, none of the bonds mentioned in Law No. 851 have ever been offered. See Reeves, supra note 116, at 985. Also, Cuba's refusal to sign the moderate United Nations Resolution on Permanent Sovereignty Over Natural Resources, which provides that deprived owners shall be paid "appropriate compensation, in accordance with the rules in force in the State, taking such measures in the exercise of its sovereignty and in accordance with international law," raises further doubt about Cuba's acceptance of the principle of compensation, even in its most general formulation. But see, N.Y. Times, March 8, 1961, p. 9, col. 1, wherein Premier Castro stated that he might consider compensation if the United States granted economic concessions to Cuba. 
"effective," its failure to define "adequate compensation" may inspire future claimants on both sides of the wealth deprivation process to invoke its decision as authority for their opposing objectives. The conflicting scholarly opinion cited by the district court for the "rule" that a failure to pay "adequate" compensation violates international law makes this clear. ${ }^{150}$ For example, Lord McNair maintains that "prompt, adequate and effective" compensation must always be paid, even in nationalizations. ${ }^{151}$ The late Sir Hirsch Lauterpacht has noted, however, that in contexts "involving fundamental changes in the political system and economic structure of the State," partial compensation may suffice.152 Article 10 of the Harvard Draft, also cited by Judge Dimock, while insisting that "adequate" and "effective" compensation represent the "fair market value of the property taken" (undepressed by anticipation of the seizure) and that it must be "in a currency which the claimant can freely use and at an exchange rate which is most favorable to him," would relax the requirement of "prompt" compensation in cases of general socio-economic reform. ${ }^{153}$ Finally, Hackworth's Digest of International Law cites voluminous and equally divergent positions.

The ambiguity already inherent in Judge Dimock's failure to define "adequate compensation" is thus intensified. Moreover, when looking to the factual circumstances upon which Judge Dimock relied, his failure to define "adequate compensation" becomes more significant. Was his conclusion based upon Cuba's decision to pay in bonds? Was it because the bonds could not be redeemed for thirty years? Was it due to Cuba's policy of unilateral valuation? Or, was it simply that United States-Cuban trade statistics rendered the compensation fund illusory? Indeed, use of the word "adequate," itself part of the orthodox trilogy and therefore associated with traditional preferences for "full" or "fair market" value, placed upon the court an especial responsibility to define that term. Clearly, failure to do so and failure to reconcile the conflicting commentaries cited limit the future authoritativeness of this decision to situations substantially similar to Banco Nacional. If this ruling is used, albeit improperly, to predict uniform restrictions which States may reasonably be expected to accept, the outmoded orthodox compensatory standard may be unduly fortified.

150193 F. Supp. at 385 n.26.

151 McNair, supra note 118, at 249-53.

152 I OPPENheim, INTERnATIONAL LAw 352 (8th ed. Lauterpacht 1955). It is not clear, however, whether Judge Lauterpacht would have further modified the orthodox standard.

153 Harvard Draft Research, Draft Convention on the International Responsibility of States for Injuries to Aliens (1961), in Sohn \& Baxter, Responsibility of States for Injuries to the Economic Interests of Aliens, 55 AM. J. INT'L L. 545, 553-54 (1961). 
The willingness of the court of appeals to avoid identifying as a fundamental principle of international law "some principle which in truth is only an aspect of the public policy of our own nation and not a principle so cherished by other civilized peoples," ${ }^{154}$ merits applause. To the extent that the court questioned the applicability and, therefore, the authoritativeness of this orthodoxy to extensive deprivation contexts, the danger that future claimants might invoke the appellate decision as authority for that standard is minimized. Nevertheless, the court found that Cuba "failed to provide adequate compensation." 155 And like the district court, the circuit court neglected to explain "adequate compensation." For the reasons outlined above, the future value of its opinion is limited.

The circuit court decision is vulnerable for yet another reason. Unnecessary confusion was generated by its refusal to hold that failure to pay "adequate" compensation is, in and of itself, a violation of international law.156 If by "adequate compensation" the court meant "prompt, adequate and effective," it properly refused to find a breach of international law for, as noted, no consensus exists on the compensatory standard applicable to extensive foreign wealth deprivations. On the other hand, if the court meant that failure to pay compensation of any kind is not of itself an international delict, it misstated the Law of State Responsibility.

The latter alternative is the more probable since the court narrowed its inquiry to whether or not failure to pay "adequate compensation" when accompanied by retaliation and discrimination violates international law. This is the minority position commonly associated with Sir John Fischer Williams who maintained that, absent treaty or contractual obligation, States are not required to compensate for the taking of alien property unless discrimination is also present. ${ }^{157}$ As the cornerstone of the Law of State Responsibility, ${ }^{158}$ however, the duty to pay

154307 F.2d at 861 .

$155 \mathrm{Id}$. at 862 .

$156 I d$. at 864 . The court of appeals was severely criticized for assuming this position by A.B.A. Commitree on International Trade and Investaient, SEction of INTERNational and Comparative Law, The Protection of Private Property Invested Abroad 10 (1963): "The doubts thus cast by one of the leading courts of the country on the international responsibility of a State for a failure to pay prompt, adequate and effective compensation for the taking of alien-owned property appear to be based on a small minority of writers, including the author of an 'unpublished paper' in the Yale Law School Library!"

157 See Williams, International Law and the Property of Aliens, 9 BRIT. YB. INT'L L. 1 (1928).

158 Indeed, we submit, if deprived aliens were given satisfactory reparation for lost investments, it is unlikely they would seriously complain of discriminatory or retaliatory treatment or of the absence of public utility in the taking. 
compensation should not be made dependent upon any other claim of illegality. If less developed nations expect to attract a constant and accelerating flow of private foreign capital, there must be at least minimal assurance that investors will not be forced to foresake entirely the fruits of their labor. As S. N. Guha Roy has noted, reparation for alien property seized is "a germinal principle of bare justice." 159 Indeed, it is perhaps the sole principle of the Law of State Responsibility which enjoys near universal acceptance, even by collectivist societies. ${ }^{160}$ Just as adherence to orthodox prescriptions of "prompt, adequate and effective" compensation raises unwarranted expectations within the private investment community, so may the circuit court's finding create among less developed nations the unjustified assumption that alien property can be taken without indemnification as long as the seizure is untainted by discrimination or retaliation. The court evidently did not realize that the concern of contemporary debate is not the principle of compensation itself, but the formulation of techniques consistent with the inclusive interests of the world community by which the timing, amount and form of compensation can be effectively determined.

The Cuban legislation pursuant to which C.A.V. was nationalized failed to meet the most minimal compensatory requirements of the Law of State Responsibility. To the extent that both courts acknowledged this fact, their decisions cannot be impugned. But their failure to project realistic policies which reciprocally derive from and nourish the common interest of the world community in achieving a creative, equitable and efficient balance between demands both for socio-economic reform and private profit gives their opinions limited utility as meaningful guidelines for future decision. Their imprecision and lack of clarity, it is feared,

169 Roy, Is the Law of Responsibility of States for Injuries to Aliens a Part of Universal International Law?, 55 AM. J. INT'L L. 863 (1961). As Grotius once stated: "Fault creates the obligation to make good the loss." GRotius, ON THE RIGHTS OF WAR AND PEACE 430 (1646 ed. Carnegie Endowment for International Peace transl., 1925). Similarly, Eagleton has stated: "Historically, the idea of a responsibility between states may be traced back to the vague origins of rights and duties which have always been regarded as fundamental by mankind. Among these is the conviction that reparations should be made for an injury committed; and this idea of responsibility, whether between persons or States, is as old as morality itself." EAGLETON, The ResponsibiLITY of STATES IN INTERNATIONAL LAW 16 (1928).

160 For commentary that the principle of compensation is accepted by members of the Communist world, in their legislation and in international agreements to which they have been parties, see WHIrE, op. cit. supra note 110, at 232-34; Bindschedler, La Protection de Propriete Privee en Droit International Public, 90 HAGUE REcEuII DES Cours 173, 252-71 (1956); Foighel, Nationalization. A Study of the Protection of Alien property in International Law, 27 NORDISK TIDSSKRIFT FOR INTERNATYONAL RET. 143, 14547 (1957); Katzarov, The Validity of the Act of Nationalisation in International Law, 22 MoDerN L. Rev. 639, 647 (1959); Seidl-Hohenveldern, Communist Theories on Confiscation and Expropriation, Critical Comments, 7 Ax. J. CoMr. L. 541 (1958). 
will only sow confusion on both sides of the foreign wealth deprivation process.

\section{Conclusion}

Looking dispassionately at the present uncertain force of the Law of State Responsibility as an effective shaping force in the struggle for foreign investment security, one cannot escape asking through what deficiencies in judgment or skill international law decision makers have failed to focus upon the trend of world affairs. To answer that recent developments have caught us unaware or that they are but temporary deviations from the "normal" flow of human events is a counterfeit apology, reflecting an artless view of history. Rather, the difficulty suggests that scholars and jurists, in quest of legal certainty, have failed to maintain a frrm grasp upon the broad policy objectives of a contemporary Law of State Responsibility.

Such was the failing of the courts in this case. Their proper dismissal of Banco Nacional's complaint, therefore, may be justified less by inspired sensitivity to the fundamental community policies at stake than by Cuba's clearly flagrant defiance of the most elemental sanction of international law in this area.

Indispensable to the effective future functioning of the Law of State Responsibility, however, and hopefully destined to distinguish the deliberations of the Supreme Court, is the creative search for and application of policy capable of meeting the challenge of new and everchanging patterns of social, economic and political interaction. Pious obeisance to allegedly precise, immutable and eternal "rules," on the other hand, serves only to wedge the mind into traditional molds and thereby to impose an impossible rigidity upon the processes of historical change.

We must therefore relinquish the deceptive notion that the Law of State Responsibility is a "brooding omnipresence in the sky" consisting of a "body of rules" which can be mathematically prescribed, invoked and applied. All legal "rules" are, in a sense, verbal mirages, fictions. They are, as Jerome Frank once described them, "but psychological pulleys, psychical levers, mental bridges or ladders, means of orientation, modes of reflection, 'As-Ifs,' convenient hypostatisations, provisional formulations, sign-posts, guides." 161 The sooner we recognize this and the sooner we focus upon the ends sought to be achieved, as well as the reasons for achieving them, the more quickly will we augment legal certainty in this area. So doing, we will also better assure the greater production and wider sharing of economic and other values.

161 Frank, LAW ANd the Modern Mind 167 (1930). 